\title{
The Teaching of Mathematics
}

$\mathrm{T}$ HE mathematical subsection $\left(\mathrm{A}^{*}\right)$ of the British Association departed this year from its usual policy of presenting papers on specialized branches of research, and its sessions at Nottingham were devoted chiefly to two discussions on the teaching of mathematics. On Saturday, September 4, Prof. E. H. Neville opened a discussion on the unification of algebra in schools. Mr. T. A. A. Broadbent condemned the older school text-books as a collection of watertight compartments, and pointed out the need for the course to be systematized and unified. Mr. G. L. Parsons contrasted the older method of putting all the emphasis on technique with the newer methods of bringing out the ideas of the subject. He favoured the approach by means of the formula or the equation rather than by tedious drill in elementary algebraic processes. Mr. M. H. A. Newman gave the university point of view, particularly as regards the importance of linear transformations and matrices. Mr. W. J. Langford pointed out that changes in the school course could not be made unless such examinations as that for the School Certificate were modified correspondingly. He suggested that teachers should agree upon a policy, and then submit alternative syllabuses to the examination authorities.
The papers attracted a large audience, including many from other sections, and the lively discussion that ensued proved that the subject was felt to be of great interest and importance.

On Tuesday, September 7, Prof. H. T. H. Piaggio opened a discussion on the bearing of higher geometry on the school course. Prof. E. H. Neville protested against the policy of drill in the application of devices of which no rational explanation had been given. Mr. H. G. Green showed how to give this explanation in the case of the 'line at infinity', and Prof. W. H. MeCrea in the case of the 'circular points at infinity'. Prof. H. S. Ruse pleaded for an extended treatment of differential geometry, including vector methods. A general discussion followed.

At the end of this discussion Mr. C. H. H. Franklin exhibited a most interesting collection of models representing four- and five-dimensional solids, by a principle analogous to that employed to represent three-dimensional solids by a sketch on two-dimensional paper.

The secretary of the subsection, Dr. Dorothy M. Wrinch, is to be congratulated on the success of the policy of replacing isolated papers by discussions on topics of wider interest.

\section{Biological Standards*}

\begin{abstract}
THE proceedings of the meeting of the Permanent Commission on Biological Standardization held at Geneva in the autumn of 1935 have been published, together with the reports of the technical experts to whom a number of different questions dealing with biological standards had been referred.

Six standards were adopted or redefined by the Commission. The pituitary (posterior lobe) powder and the Digitalis purpurea leaf powder, at present in use as standards in Great Britain, stocks of which are held at the National Institute for Medical Research, Hampstead, were adopted as international standards, and the Institute was asked to distribute them on behalf of the Health Organisation. The original international standard pituitary powder was prepared by Prof. Voegtlin and was available for issue to authorities desirous of testing their national standards, but up to that time no laboratory had been entrusted by the Commission with its general distribution : the two preparations are of the same activity. The original international digitalis standard powder is nearly exhausted; but the stock of the British Standard is sufficient for international require. ments for some time: its potency is, however, greater than that of the previous standard, so that one unit is represented by $0.08 \mathrm{gm}$. of the new standard, as compared with $0.1 \mathrm{gm}$. of the previous preparation. A crystalline sample of insulin was adopted as standard and defined as containing 22 units per mgm. The previous standard was amorphous

- Quarterly Bulletin of the Health Organisation. Special Number, November: Biological Standardisation (2). (Geneva: League of Nations ; London: George Allen and Unwin, Ltd., 1936.) Pp. 571-745
\end{abstract}

and contained 8 units in one milligram. Two standards for substances for which standards had not been previously available were recommended for adoption : one for $B$. histolyticus antitoxin, and the other for diphtheria antitoxin for use in the flocculation test. The question of the standards for arsphenamine and its derivatives was left for further consideration by a small technical committee.

It was further agreed that work should be carried out on tetanus antitoxin, poliomyelitis convalescent serum, staphylococcus antitoxin and antityphoid serum. The recommendations adopted by the inter. governmental conference on biological standardization were considered and certain subjects recommended for further examination, including the standardization of anti-anthrax serum, anti-swine erysipelas serum, anti-venom serum and the preparation of a standard Digitalis lanata leaf powder.

The bulk of the report is devoted to the reports of the experts who have been examining proposed new standards, and gives the evidence on which the Commission has based certain of its recommendations : for the details of these experiments the original report must be consulted. The separate sections deal with insulin, histolyticus antitoxin, diphtheria antitoxin, tetanus antitoxin and antipoliomyelitis convalescent serum. The bulletin also includes reports of the Standards Departments of the National Institute for Medical Research, Hampstead, and the Statens Serum Institute, Copenhagen, and concludes with a useful description of a simple laboratory method for the desiccation of serum and other protein solutions. 